\title{
3 Pragmatism, social inquiry and the method of democracy
}

\author{
Henrik Rydenfelt
}

\section{Introduction}

Democracy is difficult to define. This is in part due to the fact that the word has almost become an automatic way of denoting a correct or acceptable form of national governance. Most governments and political systems profess to be democratic although whether they are often remains a hotly debated issue, making it clear that any limited set of conditions prescribing truly democratic governance may be defeated by counterexamples. Universal suffrage will not suffice if political opposition is systematically suppressed or citizens do not practically have the opportunity to exercise their right to vote. The constitutional separation of powers and various checks and balances will not equal "democracy" unless their operation serves the central aspirations of democratic societies, such as accountability, legitimacy and the basic goods of freedom and relative equality. Democracy, in a word, is an ideal rather than an actual state of affairs already attained; accordingly, philosophical accounts of democracy mostly outline ways in which our systems of governance should be designed, implemented and participated in, rather than describing the operations of any actual state or jurisdiction.

By and large, contemporary philosophical accounts of democracy address three types of issues. The first pertains to the justification, preferability and legitimacy of a democratic form of governance. Is democracy better than its alternatives, and is it so to everyone? What do we say to those who would rather be subject to a non-democratic form of governance? A second issue concerns the nature of democratic citizenship and the extent to which citizens can be expected to make informed choices when participating in public processes. This issue is especially pertinent when philosophers claim that decisions made by way of a democratic procedure are better than those produced by alternative systems of governance. Finally, a third set of issues concerns the setup of a democratic society. Here the questions concern the procedures, constitution and institutions that a democratic society should entail, as well as the nature of citizen representation in processes of decisionmaking, including different forms of direct and representational democratic settings. 


\section{Rydenfelt}

Many philosophers have proposed that the tradition of philosophical pragmatism offers a unique perspective on democracy and the role of citizens. In what follows, I discuss one pragmatist view of democracy and democratic citizenship that is grounded in John Dewey's view of social inquiry, contrasting it with two alternative visions of democracy. The first of these alternatives, sometimes critically dubbed élitist democracy, views democracy as a competition between political and expert élites representing citizens in the political process; here, the central democratic practice of citizens is voting in recurring elections. The second vision is deliberative democracy, where citizens are expected to engage in rational discourse and arrive at a reasoned consensus as to the best decisions. Instead of voting, the central practice is participation in the form of public deliberation. Although pragmatist views have been likened to and identified with the deliberative account, I argue that key differences in the two perspectives have largely been overlooked. The pragmatist approach to democracy as social inquiry is not equivalent to deliberation. However, as I point out, this difference entails that the pragmatist must give an account of why such inquiry should be understood as democratic; in particular, the pragmatist must address and explain the role of citizens in its practice.

\section{Élitism, deliberative democracy and pragmatism}

As a descriptive term, and very broadly speaking, democracy means equality in group decision-making: everyone has an equal chance to influence a decision affecting the group, at least at some point or juncture. Central to the development of contemporary Western democracy is the family of views in political philosophy often lumped together as liberal democracy. These views emphasize the rights and freedoms of individuals, which the state is expected both to respect and uphold, and equality among individuals with respect to these rights. However, in Western democracies, decisions are made by expertinformed political élites, and citizen participation is largely limited to the selection of representatives by voting in recurring elections. Joseph Schumpeter famously codified this élitist form of democracy as the "institutional arrangement for arriving at political decisions in which individuals acquire the power to decide by means of a competitive struggle for the people's vote" $(1950,269)$. In this view, democracy is the marketplace for competing groups of political professionals and experts, and the main - or only - role for citizens is to vote in elections where the successes and failures of political leaders are assessed. The connection between political decision-making and the citizen is representation, and the central democratic practice is voting (see Held 1987; Whipple 2005).

In part as a reaction to such élitism, proponents of a deliberative view of democracy demand the participation of citizens rather than their mere representation by experts. The background of deliberative democracy is a central concern of the liberal tradition: the legitimacy of governments and the use of state power, which - beginning with John Locke (1689/1988) - liberals have 
usually predicated on the acceptability of the government or its decisions to the governed individual or citizen. This notion of legitimacy influenced the work of John Rawls who, in A Theory of Justice (1971/1999), aspired to lay the foundations of a democratic society in basic principles which would be (rationally) acceptable to all citizens, despite their differing interests and incompatible beliefs. Rawls's work sparked renewed interest in political philosophy, including an industry of criticism of the Rawlsian project, such as the so-called communitarian critiques (e.g. Walzer 1983) and less consensusoriented views of democracy (e.g. Mouffe 2013).

The concern with legitimacy, as well as Rawls's arguments that some principles are acceptable to all "reasonable" citizens, inspired a new understanding of the central processes of democratic decision-making and the role of citizens. Together with increasing demands for public participation in political decision-making, contemporary thinkers such as Jürgen Habermas (1990), Rawls (1996) and Joshua Cohen (1989) proposed that the legitimacy or justification of political decisions depends on their acceptability to all (reasonable) citizens. According to these views, democracy is to be viewed as a deliberative process of public justification. A consensus reached by citizens after rational, reasoned debate and discussion is required to justify and legitimize political decisions. The deliberative perspective provides an easy argument for democracy: democratic and participatory decision making is needed because the very forming of correct, justified or legitimate decisions require democratic procedures and the participation of large groups of citizens. Democracy just is the procedure by which we can attain justified ethical or political views. (In broad strokes, this is how the deliberative view answers the three main issues of contemporary political philosophy concerning democracy.)

Within this newly conceived debate, pragmatist philosophers began to argue for the relevance of pragmatism - especially John Dewey's views - in political philosophy. Originally a view about the meanings of concepts and propositions proposed by Charles S. Peirce in the 1870s (Peirce 1877/1992; $1878 / 1992$ ), pragmatism quickly started to denote a family of diverse views which emphasized the connection between theory and practice and attempted to elucidate the notion of truth in terms of inquiry and problem-solving. As public intellectuals of their day, two of the key classics of the pragmatist tradition, Peirce and William James had also published various pieces discussing political issues. However, it was Dewey who wrote most extensively on political philosophy, and whose views gradually gained prominence in the contemporary debate. Pragmatist views have been compared with and likened to Rawls's early and later liberalism (of his Political Liberalism, 1996), Habermas' views of discourse ethics as underlying democratic ideals and various other forms of deliberative democracy (e.g. Habermas 1990; Bohman 1998; Misak 2000; Talisse 2007).

Such a likening appears natural. Both contemporary deliberative accounts and pragmatist views are based on structurally similar considerations 


\section{Rydenfelt}

concerning the virtues of democracy. Rather than arguing for democracy based on some first-order value - such as equality or freedom - both views connect democracy with a second-order good which democratic societies, institutions and decision-making are supposed to secure. Pragmatist views tend to connect democracy with the pragmatist account of inquiry: they hold that truth(s) - at least on some issues - can only, or best, be approached within the context of democracy (or at least some set of democratic institutions and procedures). Deliberative views maintain that the validity, legitimacy or correctness of political decisions consists of, or at least depends on, their being the result of a democratic process or procedure; democracy is needful not (only) because of its being or securing something of first-order value, but in the interest of arriving at correct or justified views or valid or legitimate political decisions. However, as I now argue, there are definite and important differences in the two accounts.

\section{Social inqugiry}

A central starting point of (many) pragmatist views of democracy is the pragmatist notion of inquiry, or the process of settling opinion. In the pragmatist account, in its ordinary, everyday version, inquiry begins with doubt, or what Dewey called a problematic situation: some of our beliefs may be called into question, and inquiry is enacted to appease this doubt by attaining a revised or new belief. Scientific inquiry is this process made deliberate; it aims to continuously revise theories and test hypotheses, even those provisionally accepted by the scientific community. A central contention of the pragmatists is that such revision extends to the methods and standards of inquiry itself; our views of justification and criteria for better and worse theories and procedures are themselves the results of these practices and, as such, themselves fallible and always liable to revision. While any inquiry must rest on results already attained and (provisionally) accepted, the methods and theories of science are developed hand in hand, without any a priori guarantees as to their feasibility or correctness.

An important feature of this view of inquiry is that it is not limited to questions of what there is or, perhaps, would be - the sort of questions that we usually think science may address. Rather, it extends to normative questions of what there should be, or what ought to be done (cf. Rydenfelt 2011b; 2015a; 2015b). Critical of any hard dichotomy between descriptive and normative questions, pragmatists - beginning with Peirce - have argued that both kinds of issues can be approached with, broadly speaking, similar means, without reducing normative issues to descriptive or instrumental ones. There is no principled reason, the pragmatists maintain, why values and norms could not become the objects of a practice of deliberate revision, or scientific inquiry.

This extension of scientific inquiry to normative questions Dewey called social inquiry. He found contemporary social science to be stuck between two 
uneasy alternative approaches to the role of values in inquiry. In the first, social or societal issues are addressed in terms of blame and approbation based on preconceived moral views. Social sciences, then, rest on static and fixed, often unstated and implicit, evaluations due to custom or tradition. In the second alternative, in order to refrain from "moralising", evaluations are superficially excluded from science altogether in line with a strong dichotomy between "facts" and "values". Yet this apparent exclusion of evaluations from social science reduces such inquiry "at its very best to the truncated and distorted business of finding out means for realizing objectives already set upon" (Dewey 1938, 490). Neither alternative is satisfactory. Both rely on implicit, unstated goals and evaluations: "the values employed are not determined in and by the process of inquiry" (1938, 496).

In contrast, in Dewey's view, our values and aims (or what Dewey calls our "ends-in-view") should be treated as hypotheses to be tested by and in the process of inquiry. This extends to social and societal policy, which Dewey argues, "is, logically, and should be actually, of the nature of an experiment":

(1) it [a social policy] represents the adoption of one out of a number of alternative conceptions as possible plans of action and (2) its execution is followed by consequences which, while not as capable of definite or exclusive differentiation as in the case of physical experimentation, are none the less observable within limits, so they may serve as tests of the validity of the conception acted upon.

$(1938,502)$

In this view, the test of a value (or an end-in-view) takes place in an experiment, which is the actual adoption of social policy. The policy implemented amounts to the choice of one of a number of alternative courses of action to address a social problem, and its validity can and should be tested by way of its consequences in experience.

However, a concern will inevitably be raised. If our values (or ends-in-view) are tested by their consequences, do we not need another set of values, or ends, in light of which these consequences are assessed? It appears that experimentation with social policy can occur only if there are some further, more final values; this concern is certainly not alleviated by Dewey's occasional talk of values as "means" (cf. Westbrook 1998). Indeed, Dewey maintained that drawing from further values in social inquiry is inevitable; such inquiry "must judge certain objective consequences to be the end which is worth attaining under the given conditions" $(1938,496)$. This dependence on values, however, does not distinguish social inquiry from other lines of inquiry. Physical inquiry, Dewey pointed out, also requires values or ends: all inquiry is a process "of adjudgment, of appraisal or evaluation", as it "demands that out of the complex welter of existential and potentially observable and recordable material, certain material be selected and weighed as data [...]" (1938, 491). Both social and physical inquiry presuppose some view 


\section{Rydenfelt}

of the kind of results of experimentation that speak for or against a hypothesis. Social and physical inquiry are distinguished by their subject matters and, consequently, by the kind of operations and environments in which inquiry takes place. Nevertheless, both types of inquiry assume and require standards of justification (or confirmation or corroboration of a hypothesis by data). What is more, such standards cannot be settled in advance of such inquiry, or by means of philosophical, a priori argumentation. Rather, the standards of justification are themselves explicated, questioned, revised and determined in the process of physical or social inquiry.

Within social inquiry, what could this revision of standards mean in practical terms? The central Deweyan idea here is that the data collected within experimentation with a social policy are not used merely to show how successful the policy was in achieving the ends that it was designed to attain. The same data also speak to the viability of those ends as such: whether the ends were worthwhile in the first place; what other ends were not achieved; whether some further ends were suggested only once the policy was in place; whether the ends that the policy was designed to achieve turned out to be an aspect of some more encompassing end which should be the goal of social policy; and so on. The outcomes of the experiment speak not only to the success of the policy with respect to an initial goal, but more generally to the issue of what kind of data are taken to corroborate or disconfirm the hypothesis - that is, to the general issue of what the goals of social policy should be.

\section{The method of democracy}

Dewey's advocacy of democracy had many motivations, but his view of social inquiry was certainly one among them. In Liberalism and Social Action (1935), he aspired to distinguish the contemporary liberal ideals of democracy from what he called the method of democracy: the extension of "organized cooperative inquiry" into social issues. The background of this discussion lies in Dewey's entrenched criticism of the individualism manifested in classical liberalism and its view of politics largely as a negotiation between the clashing interests of different individuals. In the liberal view, intelligence appears as "an individualistic possession, at best enlarged by public discussion" (1935, 50), "an individual possession to be reached by means of verbal persuasion" $(1935,51)$. A vision of democratic society as comprising groups of individuals represented by political parties or factions is, in Dewey's view, an extension of this liberal view of intelligence into public decision-making. The result is a view of democracy as public discussion, where public "truths" are expected to emerge from the conflict of individual and group interests. Dewey contrasted this procedure of arriving at political "truths" with scientific inquiry:

The idea that the conflict of [political] parties will, by means of public discussion, bring out necessary public truths is a kind of political 
watered-down version of the Hegelian dialectic, with its synthesis arrived at by a union of antithetical conceptions. The method has nothing in common with the procedure of organized cooperative inquiry which has won the triumphs of science in the field of physical nature.

(Dewey 1935, 51)

The notion that discussion suffices for the discovery of physical laws and the structure of reality was replaced, in physical science, by the method of "experimental observation guided by comprehensive working hypothesis, and using all the resources made available by mathematics" $(1935,50)$. In the same vein, Dewey proposed that the notion of democracy as a public discussion should be replaced by the method of democracy - that of organized, cooperative intelligence and experimental inquiry.

Here the contrast between Dewey's method of democracy and deliberative accounts of democracy appears particularly stark. Both Dewey and the proponents of deliberative democracy maintain that democracy should be more than the "majority rule" of ballot boxes; such procedures of representation are often inadequate as means for arriving at increasingly better policies. Yet the deliberative view amounts to advocating just the kind of public discussion which Dewey admonishes for its incomplete and outdated view of ethical and political truths.

This difference between the deliberative perspective and the Deweyan method of democracy points to a divergence in their views of central motivations and aspirations for democracy. The deliberative perspective contributes to an argument for democracy and an account of the role of citizens: a democratic, deliberative process of decision-making is itself justified - or at least needful - because the formation of correct, justified or legitimate decisions requires democratic procedures and the participation of large groups of citizens. Democracy is the procedure by which we can attain justified ethical or political views. In the Deweyan view, in which the method of democracy is funded by the notion of social inquiry, the connection between such inquiry and procedures, organizations, institutions and overall societal settings which deserve to be called democratic appears less straightforward. If simple majority rule and the ideal of reasoned public debate is replaced by the experimental method in the solution of ethical, political and social issues, it is not clear why the resulting practices of social inquiry amount to the method of democracy. ${ }^{1}$ The central issues of the justification of democracy (or the legitimacy of democratic decisions), the procedures and institutions of a functioning democracy and a feasible account of the role of citizens and citizen participation, require a new response.

Many contemporary pragmatist views of democracy have drawn upon the connection between democracy and (social) inquiry in order to address these central issues of contemporary political philosophy. This is a natural move to make. As already pointed out, emphasizing this connection is perhaps the most distinctive contribution of pragmatism to political philosophy. However, 


\section{Rydenfelt}

as the doubts already presented reveal, the connection is also somewhat delicate. Even if the pragmatist view of social inquiry does underwrite an account of democracy, it is far from clear what such a democracy entails. To bring this issue into sharper relief, I now briefly explore the views of contemporary pragmatists.

\section{The pragmatist argument(s) for democracy}

It is doubtful that Dewey - or any of the other classics of pragmatism attempted to formulate an argument that would meet the contemporary challenge of justifying or legitimizing democracy. Dewey's views of social inquiry were only a part of his motivation and conception of democracy. He held that democracy is "more than a form of government; it is primarily a mode of associated living, of conjoint communicated experience" (Dewey 1916, 93). He proposed a commitment to democracy as a way of life that should permeate every form and aspect of human association (e.g. Dewey 1927, 325), and viewed democracy as integral to human flourishing or what he calls "growth". This commitment to democracy has come at a price: Dewey's views in particular have been criticized for creed-like obstinacy (cf. Talisse 2010), while the connection between democracy and growth - as well as the concept of growth more generally - has been found obscure (cf. Hildreth 2011). To remedy this situation, contemporary pragmatists have attempted to formulate arguments that would address present-day concerns with the justification of democracy based on the writings of the classical pragmatists, especially Dewey and Peirce.

Among contemporary pragmatists, it appears that the first to explicitly formulate a pragmatist argument for democracy explicitly is Hilary Putnam (1992; 1994), who claimed to draw it from Dewey. In Putnam's version, the argument has two premises. The first is a pragmatist view of ethical and political truth already explored: ethical and political truths are (or at least may be) discoverable in a process of inquiry (e.g. Putnam 1992, 186). Putnam's second premise is that such inquiry requires democratic standards and ideals in a society. In his view, this latter premise is an empirical claim, which maintains that a "hierarchical" (that is, non-democratic) society "limits the rationality of those at both ends of the hierarchy" (Putnam 1994, 175). Hierarchy "stunts the intellectual growth of the oppressed, and forces the privileged to construct rationalizations to justify their position" (ibid.). Hierarchical societies, Putnam maintains "do not, in these respects, produce solutions to value disputes that are rationally acceptable" (ibid.). Thus, Putnam concludes, we should organize our societies in a democratic fashion, because that is what successful ethical and political inquiry requires; democracy is - at least to the extent that we desire to promote the growth of human intelligence and knowledge - preferable to its alternatives.

Other pragmatists have derived further conclusions based on similar premises. Drawing mainly from Peirce's notion of inquiry, Robert B. Talisse 
(2007; 2010) has attempted to show that (liberal) democracy is a legitimate form of governance in the sense advanced by the tradition of political liberalism: that democracy is acceptable to all reasonable citizens. If we are interested in learning the truth concerning any issue, Talisse maintains, we are already committed to certain conceptions of good evidence, reasons, justification and inquiry; moreover, these conceptions are democratic. This account is indebted to Cheryl Misak's (2000) defence of democracy, which revolves around what she calls the pragmatist methodological principle that "the experience of others must be taken seriously" (Misak 2000, 6). As agents with beliefs, Misak maintains, we are already seeking the truth; truth is, in a familiar dictum, the aim of belief. Seeking truth, in turn, means that we are already committed to a notion of reasons for belief which includes the relevance of the experiences and arguments of various others. If our opinions are to be settled so as to withstand the experience and argument of potentially everyone, the views and experiences of all may be relevant to our inquiries. Everyone thus must have the chance to express their opinion in moral debates; the methodological principle "requires a democracy in inquiry" (Misak 2000, 6).

It is doubtful, however, that such arguments can convince those who do not already share a number of crucial assumptions - for instance, those citizens who maintain non-democratic views (cf. Rydenfelt 2011a; Rydenfelt in press). Putnam's first premise already entails a substantial view of ethical and political issues: that we can, and should attempt to, solve them by way of scientific inquiry rather than, say, by simple reliance on tradition or religious creed. The same ideal of inquiry is also reflected in the second premise. As we saw, in Putnam's view, non-democratic societies curtail the rationality of the citizens at both ends of a hierarchical spectrum, leading to solutions to ethical problems which are not rationally acceptable. This is how things are from the pragmatist point of view: the pragmatist thinks that the methods and aims of inquiry are empirical discoveries, and not based on a priori conceptions of rationality, reasons, evidence and the like. Yet, for the argument to succeed, we must already accept the pragmatist view of how rationally acceptable or justified solutions of value disputes can be achieved - something that not everyone is likely to accept. The problem is all the more urgent when similar premises are used to show that democratic use of state power is legitimate in the sense of being acceptable to all citizens. In Talisse's version, the pragmatist argument is deployed to circumvent the problem of founding democracy on substantial ethical and political views that may be rejectable by some citizens. However, even if this view of democracy is not centred on some comprehensive ethical view, to accept it we must still share a number of assumptions concerning rationality, truth and the requirements of good inquiry - in other words, a comprehensive epistemic view (cf. Rydenfelt 2011a; 2013).

Concentrating on the original issue of the connection between democracy and the pragmatist view of inquiry, we might grant the first premise as well as 


\section{Rydenfelt}

its consequences for the empirical revisability of the standards of rationality or justification. Perhaps the arguments at hand do not convince those who do not share the pragmatist view of inquiry into ethical and political issues; nevertheless, this is what the distinctively pragmatist view of democracy maintains. Even then, however, the second premise of Putnam's argument faces a challenge. Putnam maintains that this premise is empirical. Is it really obvious that experiences of inquiry - either in general, or into ethical issues in particular - have led us to think that inquiry can only (or even best) be pursued in a democratic setting? Putnam himself admits that sometimes full "democratization" is not a prerequisite of scientific inquiry: such inquiry may be conducted, for example, when a tyrant allows limited freedom of speech among a group of physicists engaged in specific research (1994, 175). Yet one might argue that this is the case of inquiry more generally. While it seems clear that the advancement of science does depend on the availability of information - at least of previous studies and empirical data - high quality science has been performed in contexts which are by no means democratic. Perhaps good science involves some elements of democratic governance, but it seems hardly evident that its progress presupposes a democratic societal setting. Why should things be any different in the case of inquiry into ethical and political issues?

\section{The role of citizens}

The question arrived at concerns the role of citizens. Again, consider the contrast between the pragmatist view and deliberative democracy. In the latter view, citizens must be involved and included in public deliberation; the test of the correctness, validity or legitimacy of political decisions is that a consensus is reached among them. In the pragmatist view, deliberation and consensus has no such role; rather - at least in contemporary accounts - it is argued that inquiry into ethical, political and societal issues demands "democracy". But how? What is the role of "ordinary" citizens in such inquiry?

The answer that many contemporary pragmatists have supplied is that the knowledge, particular perspective and experiences of any citizen may contribute to the advancement of inquiry. Drawing mainly from Peirce but also from Dewey, Cheryl Misak, as we saw, has pointed out that the experiences of everyone may be relevant to ethical and political inquiry. Similarly, Elizabeth Anderson (2006) has argued that Dewey's experimentalist view of inquiry entails the inclusion of citizens of diverse backgrounds, opinions and the like. In Anderson's view, the exclusion of some citizens would hinder the "ability of collective decision-making to take advantage of citizens' situated knowledge the fact that citizens from different walks of life have different experiences of problems and policies of public interest, experiences that have evidential import for devising and evaluating solutions"; in contrast, "[u]niversal inclusion makes maximal use of such situated knowledge" (Anderson 2006, 34). 
James Bohman, in turn, has argued that the "epistemic benefits of democracy", in Dewey's view, "derive from a practice of deliberation in which many different perspectives are brought to bear in an ongoing process of formulation, testing, and revision" (Bohman 2010, 53). ${ }^{2}$

While the idea of the potential benefits of drawing from the knowledge accrued by large numbers of people (or citizens) is part of the connection which Dewey made between democracy and social inquiry, as defences of the relevance of the views of "ordinary" citizens these accounts suffer from serious problems. It is unclear - at least unless much more is said of the contribution that citizens are expected to make - why the same information and knowledge would not be possessed, or at least very easily acquired, by experts. Indeed, these views of the role of citizens risk reducing the intelligence operative in inquiry to the potential contribution of individual intellects - that is, to the compound of individual knowledge - rather than viewing that intelligence as encompassing the whole process of testing social policy. That is, these views threaten to obfuscate the experimental nature of social inquiry. For example, although Bohman lists different stages of the scrutiny of a hypothesis - formulation, testing and revision - it appears that the (democratic) process of inquiry is still understood as the collection of information in a conversation between different "perspectives" and the interests they include in a process of deliberation. Such collection of information is needful to identify the issues and problems at hand and to formulate initial ideas for solutions. As Dewey had it, "fact-finding procedures are necessary for (1) determination of problems and for (2) provision of data that indicate and test hypotheses" $(1938,500)$. However, the ultimate test of a social policy is in its observable consequences when put into action by means of experiment.

Indeed, rather than the relevance of individual contribution to knowledge, it is the experimental nature of social inquiry that ultimately makes the engagement of "ordinary" citizens needful. Unlike in physical science advanced in the laboratory or observatory, the experiments of social inquiry must be actionable in the actual association of actual people. Dewey went so far as to say that this must a part of the very process of devising a hypothesis: "Any hypothesis as to a social end must include as part of itself the idea of organized association among those who are to execute the operations it formulates and directs" (1938, 496). Moreover, attributing some bearing and significance to the consequences of an experiment requires that those consequences take place in human practice. The relevance and significance of those consequences cannot be determined, Dewey maintained, except by "active or 'practical' operations conducted according to an idea which is a plan" $(1938,504)$. Social inquiry, then, would be impossible - at least in our current conditions - without citizens both willing to engage in its practical operations and organized, in groups and as a society, in a fashion that makes experimentation with social policy possible. ${ }^{3}$ Social inquiry cannot begin unless the required societal organization and the willingness to participate are in place. 
What would this process of experimentation look like in practice? The starting point of social inquiry is a problematic situation. Such inquiry must begin with an attempt to identify societal problems, formulate them in an accessible manner and devise hypotheses concerning possible solutions. This part of the process is close to deliberation, wherein "ordinary" citizens can participate and present their views of the problems they are facing, identify shared problems and propose different ideas for possible solutions. However, this is just one stage of social inquiry. After the problem has been identified and hypotheses concerning its solution have been devised, the hypothesis - a social policy - is then introduced to human practices. The role of citizens, at this stage, is to engage in their everyday social practices affected by the new policy. The outcomes generated are then assessed; for the collection of such data, the input of citizens and their views of the outcomes and their relevance are needful. The method of democracy involves not only discussion and deliberation to identify problems and possible solutions, nor only an assessment of results, but includes both as stages of the experimentation of policy within human practices. Although the process itself can be expert-driven, citizens' participation is required for the success of the overall process of inquiry: without their contribution at each stage, the inquiry could not be conducted.

Accordingly, we can make some sense of Dewey's proposal that democracy should permeate every form of human association. This was not to imply that we should decide everything by majority rule. The pragmatist view of democracy is a relatively radical one; it is not wedded to many of the features of contemporary Western societies with which we have grown accustomed to identify democracy: certain institutions, representational forms of government, voting, elections and so on. A successful implementation of the pragmatist vision doubtless requires that some (aspects of) these institutions are in place. Social inquiry would likely be stymied by an absence of free speech or the kind of educational institutions which produce experts able to engage in social inquiry, as well as citizens willing to engage in that process. However, the traditional institutions of Western democracy may themselves be subject to gradual revision in the search for better ways in which to devise and revise social and societal policy.

\section{Conclusion}

The pragmatist perspective on democracy is distinct from élitist and deliberative views of democracy. Rather than citizen representation and voting or participating in public deliberation, the starting point of the pragmatist perspective is a view of social inquiry into normative issues as a form of experimental science. This "method" of democracy, however, requires an articulation of the role of (ordinary) citizens: why is this inquiry not best conducted by merely by experts? I have proposed that social inquiry involves citizens participating in the improvement of social policy in terms of their 
everyday practices. It is this understanding of the connection between social inquiry and actual, everyday social practices that gives content to the pragmatist insistence that inquiry requires "democracy". Ordinary citizens' engagement in various stages of the experimental process is needful for its success. Accordingly, if there is a pragmatist "justification" of democracy, it is this: social inquiry requires more than experts. Fashioning democracy through the lens of social inquiry means, however, that the pragmatists - like Dewey - are unlikely to provide a detailed account of any fixed institutional and constitutional requirements of democracy. In line with the processes of any experimental line of inquiry, the specific methods of social inquiry are always subject to revision.

\section{Notes}

1 This is not to say that the deliberative view is without its problems; indeed, it is vulnerable to a relatively simple counterargument. Although deliberative democracy is not founded on the (alleged) acceptance of some particular (first-order) value, it nevertheless rests on a substantial conception of the correctness, justification or legitimacy of ethical and political views as a product of a free, rational, consensus-yielding discussion (cf. Rydenfelt 2013). This conception can be rejected by some citizens, rendering the justification of democracy suspect at least from some points of view. The same is the case with the more particular ideals and practices that theorists have suggested are integral to the deliberative process, such as the tolerance of pluralism of opinion and equality in making and criticizing proposals for policy (cf. Cohen 1989).

2 This is where pragmatism also promises to bridge the gap between the consensusoriented, liberal view and the agonist version of democracy that opposes it. The high bar of legitimacy set by the demand of acceptability to all citizens has been extended to act as the basis of foundational democratic principles (Rawls), and a rational consensus has been advanced as a criterion for the correctness of moral and political views (Habermas, many deliberative theorists). According to critics such as Chantal Mouffe (2013), such a view risks downplaying the conflict of views that occurs in a democratic societal setting. By analogy with scientific inquiry, the pragmatist can argue that democracy requires both moments of consensus and conflict; while relative uniformity of opinion about some central aims and values is needful to provide the starting points of such inquiry, diversity and pluralism of opinion provides the impetus necessary for constant revision of even well entrenched views.

3 It should be noted that technological development - especially advances in simulation and virtual reality - may eventually reduce the need to test social policies in actual human practices. However, while computer simulations, for example, can be deployed to test social policies against their desired ends-in-view, it is not at all clear whether simulations can ultimately provide data sufficient for the testing of those ends themselves.

\section{References}

Anderson, E. (2006). The epistemology of democracy. Episteme, 3(1-2), 8-22.

Bohman, J. (1998). Survey article: The coming of age of deliberative democracy. The Journal of Political Philosophy, 6(4), 400-425. 


\section{Rydenfelt}

Bohman, J. (2010). Participation through publics: Did Dewey answer Lippmann? Contemporary Pragmatism, 7(1), 49-68.

Cohen, J. (1989). Deliberation and democratic legitimacy. In A. Hamlin \& P. Pettit (Eds.). The good polity: Normative analysis of the state (pp. 17-34). New York: Blackwell.

Dewey, J. (1916). Democracy and education. In J.A. Boydston (Ed.). The middle works of John Dewey (Volume 9, pp. 1-370). Carbondale: Southern Illinois University Press.

Dewey, J. (1927). The public and its problems. In J.A. Boydston (Ed.). The later works of John Dewey (Volume 2, pp. 235-372). Carbondale: Southern Illinois University Press.

Dewey, J. (1935). Liberalism and social action. In J.A. Boydston (Ed.). The later works of John Dewey (Volume 11, pp. 1-66). Carbondale: Southern Illinois University Press.

Dewey, J. (1938). Logic: The theory of inquiry. In J.A. Boydston (Ed.). The later works of John Dewey (Volume 12, pp. 1-528). Carbondale: Southern Illinois University Press.

Habermas, J. (1990). Moral consciousness and communicative action (C. Lenhardt \& S. W. Nicholsen, Trans.). Cambridge: Polity Press.

Held, D. (1987). Models of democracy. Stanford, CA: Stanford University Press.

Hildreth, R.W. (2011). What good is growth? Reconsidering Dewey on the ends of education. Education \& Culture, 27(2), 28-47.

Locke, J. (1988). Two treatises of government (Peter Laslett, Ed.). Cambridge: Cambridge University Press. (Original work published 1689).

Misak, C. (2000). Truth, politics, morality: Pragmatism and deliberation. London: Routledge.

Mouffe, C. (2013). Agonistics: Thinking the world politically. London \& New York: Verso.

Peirce, C.S. (1992). The fixation of belief. In N. Houser \& C. Kloesel (Eds.). The essential Peirce (Volume 1, pp. 109-123). Bloomington: Indiana University Press. (Original work published 1877).

Peirce, C.S. (1992). How to make our ideas clear. In N. Houser \& C. Kloesel (Eds.). The essential Peirce (Volume 1, pp. 124-141). Bloomington: Indiana University Press. (Original work published 1878).

Putnam, H. (1992). Renewing philosophy. Cambridge, MA: Harvard University Press.

Putnam, H. (1994). Pragmatism and moral objectivity. In J. Conant (Ed.). Words and life (pp. 151-182). Cambridge, MA: Harvard University Press.

Rawls, J. (1996). Political liberalism. New York: Columbia University Press.

Rawls, J. (1999). A theory of justice (Revised edition). Cambridge, MA: Belknap Press. (Original work published 1971).

Rydenfelt, H. (2011a). Naturalism and normative science. In J. Knowles \& H. Rydenfelt (Eds.). Pragmatism, science and naturalism (pp. 15-38). Berlin and New York: Peter Lang.

Rydenfelt, H. (2011b). Epistemic norms and democracy. Metaphilosophy, 42(5), 572-588.

Rydenfelt, H. (2013). Constructivist problems, realist solutions. In J. Kegley \& K. Skowronski (Eds.). Persuasion and compulsion in democracy (pp. 153-169). Lanham, MD: Lexington Books.

Rydenfelt, H. (2015a). Pragmatism, objectivity and normative science. In U. Zackariasson (Ed.). Action, belief and inquiry: Pragmatist perspectives on science, society and religion (pp. 69-93). Helsinki: Nordic Pragmatism Network. 
Rydenfelt, H. (2015b). Emotional interpretants and ethical inquiry. Sign System Studies, 43(4), 501-513.

Rydenfelt, H. (in press). Democracy and moral inquiry: Problems of the methodological argument. Transactions of the Charles S. Peirce Society.

Schumpeter, J. (1950). Capitalism, socialism, and democracy (3rd ed.). New York: Harper \& Row.

Talisse, R.B. (2007). A pragmatist philosophy of democracy. London: Routledge.

Talisse, R.B. (2010). Peirce and pragmatist democratic theory. In M. Bergman, S. Paavola, A. Pietarinen \& H. Rydenfelt (Eds.). Ideas in action: Proceedings of the applying Peirce conference (pp. 105-116). Helsinki: Nordic Pragmatism Network.

Walzer, M. (1983). Spheres of justice. New York: Basic Books.

Westbrook, R.B. (1998). Pragmatism and democracy: Reconstructing the logic of John Dewey's faith. In M. Dickstein (Ed.). The revival of pragmatism: New essays on social thought, law, and culture (pp. 128-140). Durham, NC: Duke University Press.

Whipple, M. (2005). The Dewey-Lippmann debate today: Communication distortions, reflective agency, and participatory democracy. Sociological Theory, 23(2), 156-178. 